\title{
PENINGKATAN KAPASITAS KADER KESEHATAN DALAM MENDETEKSI KATARAK DI KECAMATAN JATINANGOR KABUPATEN SUMEDANG
}

\author{
Sri Sulastri ${ }^{1}$, Shanti Fitrianti Boesoirie ${ }^{2}$ dan Ute Lies Siti Khodijah ${ }^{3}$ \\ ${ }^{1}$ Fakultas Ilmu Sosial dan Ilmu Politik Universitas Padjadjaran, \\ ${ }^{2}$ Fakultas Kedokteran Universitas Padjadjaran, \\ ${ }^{3}$ Fakultas Ilmu Komunikasi Universitas Padjadjaran \\ E-mail: sri.sulastri@unpad.ac.id
}

\begin{abstract}
ABSTRAK. Katarak merupakan penyebab utama (51 persen) dari kebutaan di Indonesia. Namun, katarak dapat ditangani dengan tindakan operasi. Terdapat indikasi bahwa pelayanan operasi katarak belum dimanfaatkan dengan baik disebabkan oleh data mikro penderita katarak yang tidak tersedia. Oleh karena itu, penyediaan data mikro penderita katarak perlu dilakukan, seperti yang direkomendasikan oleh World Health Organization melalui Vision 2020. Dalam mengidentifikasi warga yang diduga menderita katarak, komponen komunitas dapat dilibatkan melalui peningkatan kapasitas dan pengorganisasian komunitas. Kegiatan Pengabdian kepada Masyarakat ini ditujukan untuk meningkatkan kapasitas kader kesehatan dalam menyediakan data mikro warga yang diduga penderita katarak dan dalam melakukan pendampingan kepada pasien dan keluarganya saat menjalani tindakan operasi, melalui kegiatan pelatihan. Hasil pelatihan ini, Kader Kesehatan: 1) mengetahui ciri katarak, 2) terampil menggunakan alat bantu identifikasi katarak, 3) mampu melakukan pencatatan data, 4) mengetahui alur pelaporan 5) mampu melakukan pelaporan, dan 6) mengetahui cara pendampingan pasien dalam mengakses pelayanan tindakan operasi katarak.
\end{abstract}

Kata Kunci: Identifikasi Katarak, Pengembangan Kapasitas, Pekerjaan Sosial Bidang Kesehatan Masyarakat, Intervensi Komunitas, Pengorganisasian Komunitas.

ABSTRACT. Cataracts are the main cause (51 percent) of blindness in Indonesia. However, cataract can be treated with surgery. There are indications that the services of cataract surgery has not been utilized properly caused by micro data of cataract patients are not available. Therefore, the provision of micro data of cataract patients need to be done as recommended by World Health Organization through Vision 2020. In identifying citizens of suspected of cataracts patients, components of community can be involved through capacity building and community organizing. Community Service activities have been carried out with the aim of increasing the capacity of health workers in providing micro data of citizens suspected of cataract patients and in assisting patients and their families while undergoing surgery, through training. The result of this training, health cadres: 1) know the characteristics of cataracts, 2) skillfully use the tools to identify cataracts, 3) capable of recording data, 4) know the reporting lines 5) able to do reporting, and 6) know how to assisting patients in accessing services of cataract surgery.

\section{Key words: Cataract Identification, Capacity Building; Public Health Social Work, Community Level Intervention, Community} Organizing.

\section{PENDAHULUAN}

Di Indonesia, katarak merupakan penyebab utama (51\%) kebutaan. Buta katarak dapat mengganggu produktivitas penderitanya. Jumlah penderita katarak di Indonesia menempati urutan kedua terbanyak di antara negara-negara ASEAN. Menurut hasil Riset Kesehatan Dasar (Riskesdas) 2013, prevalensi katarak di Indonesia sebesar 1,8\%; prevalensi katarak tertinggi berada di Provinsi Sulawesi Utara $(3,7 \%)$ dan terendah di DKI Jakarta (0,9\%); di Provinsi Jawa Barat sebesar $1,5 \%$. Faktor risiko utama penyebab katarak adalah usia (Asbell et al., 2005) Lensa dibentuk oleh protein (35\%) dan air (65\%); seiring dengan bertambahnya usia, terjadi pula perubahan degeneratif pada protein. Perubahan komposisi protein, air ditambah lagi dengan enzim dan bahan kimia lainnya akan membentuk katarak. Oleh Karena itu penderita katarak akan selalu ada, dan jika tidak dapat ditangani maka kemungkinan jumlahnya akan terus bertambah seiring dengan pertambahan jumlah penduduk, khususnya penduduk lanjut usia. Perkiraan insiden katarak adalah $0,1 \%$ per tahun, artinya setiap tahun diantara 1.000 orang penduduk Indonesia terdapat seorang penderita katarak baru (Kementerian Kesehatan RI, 2014:9).

Data prevalensi katarak adalah data makro yang merupakan perkiraan dari hasil temuan kasus pada sejumlah sampel tertentu. Dengan demikian hanya dapat diperkirakan jumlahnya tetapi tidak dapat diketahui siapa dan dimana alamatnya. Pada saat ini, pengumpulan data mikro penderita katarak (berdasarkan nama dan alamat) belum dilakukan secara sistematis. Ketidaktersediaan data mikro penderita katarak dapat menghambat penyebaran informasi penanganannya; padahal buta katarak dalam kondisi tertentu dapat ditangani dengan tindakan operasi.

Di Kecamatan Jatinangor, menurut Petugas Pelaksana Program Kesehatan Indra Puskesmas DTP Jatinangor, pengumpulan data mikro penderita katarak belum pernah dilakukan secara khusus, apalagi dengan melibatkan kader kesehatan. Informasi ini selaras dengan pernyataan Koordinator Kader Kesehatan di Desa Cilayung yang merupakan salah satu Desa di Kecamatan Jatinangor, bahwa mereka belum mengetahui sama sekali tentang katarak dan tidak pernah mendengar informasi 
tentang keberadaan pelayanan katarak secara cumacuma bagi penderita dari kalangan keluarga miskin yang diselenggarakan oleh Dinas Kesehatan Kabupaten Sumedang ataupun Rumah Sakit Mata Cicendo. Informasi tersebut menunjukkan bahwa pelaksanaan fungsi Puskesmas dalam penemuan kasus katarak belum sepenuhnya dilakukan. Padahal Petugas Program Kesehatan Indera memiliki tugas untuk melaksanakan program pelayanan inovatif kesehatan indera berupa upaya pelayanan kesehatan mata/pencegahan kebutaan. Diantara rincian tugasnya, terdapat tugas penemuan kasus katarak pada penduduk usia $>45$ tahun; penemuan orang-orang berisiko katarak, dan yang memiliki tandatanda kekurangan Vitamin A.

Alasan yang dikemukan terkait dengan belum dilaksanakannya fungsi Puskesmas tersebut adalah karena sumberdaya manusia yang terbatas sementara sasaran layanan relatif banyak. Selain itu, Puskesmas Jatinangor merupakan Puskesmas DTP (Dengan Tempat Perawatan); para petugas tidak saja melayani para pengunjung di siang hari tetapi juga bertugas piket di malam hari, sehingga waktu mereka relatif terbatas. Oleh karena itu, pihak Puskesmas pun menyambut baik kegiatan pengabdian kepada masyarakat (PKM) ini, yang bertujuan untuk mengembangkan kapasitas Kader Kesehatan dalam mendeteksi warga terduga penderita katarak.

Berdasarkan informasi dari Instalasi Oftalmologi Komunitas Rumah Sakit Mata Cicendo, pelayanan operasi katarak bagi penderita yang tidak mampu dapat dilakukan melalui kegiatan Bakti Sosial. Dalam kegiatan ini, pasien penderita katarak mendapat pelayanan tindakan operasi secara cuma-cuma. Jika lebih dari 20 penderita/ mata yang akan dioperasi berasal dari wilayah yang sama dan wilayah tersebut adalah daerah yang relatif sulit untuk dijangkau, maka tindakan operasi dapat dilakukan di lokasi dimana sebagian besar penderita tersebut berdomisili. Dalam hal ini Puskesmas dapat memberikan fasilitasi dengan cara berkoordinasi dengan Instalasi Oftalmologi Komunitas Rumah Sakit Mata Cicendo dan Dinas Kesehatan Kabupaten setempat. Fasilitas ini merupakan salah satu alternatif yang dapat dimanfaatkan oleh Puskesmas Jatinangor dalam mengatasi penderita buta katarak di wilayah kerjanya. Kalau pun wilayah Kecamatan Jatinangor bukan merupakan wilayah sulit dijangkau, namun jika aksesibilitas penderita katarak ini difasilitasi oleh Puskesmas maka proses pelayanan operasi katarak dapat dilakukan lebih cepat dibandingkan dengan jika penderita mengurusnya secara perorangan. Oleh karena itu, penderita katarak penting untuk ditelusuri keberadaannya dan dilakukan pencatatan.

Selain ikut serta dalam penemuan kasus warga terduga penderita katarak, Kader Kesehatan juga dapat berperan sebagai pendamping penderita katarak ketika warga benar-benar dinyatakan menderita buta katarak, baik selama persiapan untuk menjalani tindakan operasi maupun setelahnya. Kader Kesehatan dapat membantu menyebarkan informasi tentang persyaratan yang harus dipenuhi, baik persyaratan administratif maupun kondisi fisik yang harus terpenuhi sebelum tindakan operasi; dan perilaku yang harus dilakukan pasien setelah tindakan operasi. Kader dapat turut memastikan bahwa semua persyaratan tersebut dipenuhi.

Kegiatan pengabdian kepada masyarakat ini dilakukan di Desa Cilayung Kecamatan Jatinangor Kabupaten Sumedang. Lokasi ini dipilih karena berada di sekitar Kampus Universitas Padjadjaran Jatinangor dan di wilayah ini belum pernah dilakukan upaya peningkatan kapasitas kader dalam mendeteksi katarak. Selain itu, berdasarkan informasi dari pihak Puskesmas DTP Jatinangor, kader kesehatannya memiliki kinerja relatif baik.

Proses identifikasi warga terduga penderita katarak, dapat dilakukan dengan menggunakan sumber daya Kader Kesehatan; sebagaimana pernah dilakukan di dua Desa di Kecamatan Cidaun Kabupaten Cianjur (Sulastri dkk, 2015). Terdapat beberapa keuntungan jika mereka dilibatkan dalam proses identifikasi, yakni: 1) mereka sudah terbiasa menjadi petugas yang menghubungkan warga di wilayahnya dengan lembaga pelayanan kesehatan, baik di tingkat RW melalui Posyandu dan Posbindu, di tingkat Desa melalui Poskesdes, dan di tingkat kecamatan melalui Puskesmas; 2) mereka sudah terbiasa melakukan pencatatan dan pelaporan data warga sasaran layanan, seperti ibu dan anak balita, warga yang rentan menderita sakit, dan para lansia; dan 3) relasi Kader Posyandu dengan warga relatif lebih intens, sehingga kemungkinan penemuan kasus penderita katarak lebih tinggi. Upaya Pelibatan masyarakat dalam pembangunan kesehatan pernah juga dilakukan oleh Rodiah dkk. (2016) melalui kegiatan Pemberdayaan Kader PKK dalam Penyebarluasan Informasi Kesehatan, dan oleh Gita dkk. (2016) melalui kegiatan Peningkatan Pengetahuan Kader mengenai Kanker Payudara dan Pelatihan Pemeriksaan Payudara Sendiri (Sadari).

Di desa-desa di Kecamatan Cidaun Kabupaten Cianjur, Kader Kesehatan mampu melakukan identifikasi warga terduga menderita katarak dan cukup mampu melakukan pendampingan pada saat pelayanan operasi katarak. Kegiatan pengabdian kepada masyarakat ini merupakan reflikasi dari kegiatan yang pernah dilakukan di Kecamatan Cidaun dalam kegiatan penelitian unggulan perguruan tinggi tahun 2015 yang bertujuan untuk merumuskan model penanganan katarak berbasis komunitas.

\section{METODE}

Kegiatan pengabdian kepada masyarakat ini bertujuan untuk meningkatkan kapasitas sumber daya Kader Kesehatan atau Kader Posyandu dalam mendeteksi katarakmelaluikegiatan pelatihanagarmampumenemukan kasus warga terduga penderita katarak, sekaligus mampu 
melakukan pencatatan dan pelaporan sesuai dengan yang diperlukan oleh penyelenggara pelayanan operasi katarak. Secara spesifik, setelah mengikuti kegiatan pelatihan, Kader Kesehatan diharapkan mampu: 1) mengenal ciri katarak, 2) terampil menggunakan alat bantu identifikasi katarak, 3) mampu melakukan pencatatan data, 4) mengetahui alur pelaporan 5) mampu melakukan pelaporan, dan 6) mampu melakukan pendampingan pasien.

Pendampingan bagi pasien dan keluarganya merupakan keterampilan yang harus dimiliki oleh Kader Kesehatan selain mendeteksi katarak; karena mengatasi masalah non-medis seringkali lebih rumit dibandingkan dengan mendeteksi warga terduga penderita katarak. Kader tidak hanya akan berhadapan dengan warga terduga penderita katarak tetapi juga dengan keluarganya yang kadang-kadang kurang memberikan dukungan sehingga penanganan katarak tidak dapat dilakukan. Keinginan pasien untuk terbebas dari gangguan katarak dan dukungan keluarga sangat diperlukan dalam pelayanan tindakan operasi.

Untuk mencapai tujuan tersebut, dilakukan kegiatan pelatihan dengan menggunakan pendekatan model deduktif, yakni penyusunan materi pelatihan didasarkan pada hasil identifikasi kebutuhan pelatihan secara umum untuk kelompok sasaran yang mempunyai ciri yang sama (Kamil, https://www.academia.edu/6077358/ MODEL-MODEL_PELATIHAN_Oleh_Mustofa_ Kamil?auto=download). Kader Posyandu secara umum dianggap memiliki pengetahuan dan keterampilan yang relatif sama di bidang pelayanan kesehatan, namun untuk mengantisipasi kecenderungan keanekaragaman dalam minat dan kebutuhan belajar yang dapat menghambat pencapaian tujuan pelatihan diperlukan proses "seleksi" yang dilakukan oleh Ketua Kader Posyandu berdasarkan rekam jejak Kader dalam kegiatan Posyandu. Selain itu, diterapkan perlakuan khusus jika terdapat Kader yang mengalami masalah dalam penguasaan materi pelatihan.

\section{HASIL DAN PEMBAHASAN}

Kegiatan peningkatan kapasitas Kader Kesehatan dalam mendeteksi katarak ini dilaksanakan dalam beberapa tahap: 1) Sosialisasi Program kepada pihak Puskesmas DTP Jatinangor, Koordinator Kader Posyandu, Kepala Desa Cilayung beserta Staf, dan Pengurus PKK; 2) Persiapan pelatihan; dan 3) Pelaksanaan Pelatihan.

\section{Sosialisasi Program}

Sosialisasi program ke pihak Puskesmas DTP Jatinangor ditujukan untuk mendapatkan ijin melakukan kegiatan di wilayah kerjanya, sekaligus untuk mendapatkan dukungan; karena pada tahap berikutnya Puskesmas memiliki tanggung jawab untuk melakukan pembinaan kepada Kader agar dapat melaksanakan tugasnya secara berkelanjutan. Petugas Program Kese- hatan Indra, seyogyanya dapat menjalin kerjasama dengan para kader yang sudah mengikuti pelatihan ini. Mereka merupakan mitra kerja yang dapat berkontribusi membantu pelaksanaan tugasnya dalam mengatasi masalah buta katarak yang diderita oleh warga, terutama yang termasuk kelompok masyarakat miskin.

Pihak Puskesmas menyambut baik kegiatan ini dan pada dasarnya mengijinkan untuk melakukan kegiatan di Desa Cilayung. Para kader kesehatan yang akan mengikuti pelatihan merupakan mitra kerja dalam pelaksanaan tugasnya dalam upaya mencegah dan mengatasi masalah kesehatan mata, salah satunya buta katarak.

Sosialisasi kepada Koordinator Kader Posyandu ditujukan untuk menjelaskan tujuan kegiatan ini dan memastikan kesediaan Kader untuk mengikuti kegiatan ini. Selain itu, Ia diminta untuk menginformasikan bahwa setiap Posyandu dapat mengirimkan dua orang perserta pelatihan yang memiliki komitmen tidak hanya sekedar mengikuti pelatihan tetapi bersedia terus melaksanakan tugasnya sebagai "Kader Katarak". Koordinator Kader Posyandu pun bersedia mengikuti kegiatan pelatihan ini karena menurutnya akan menambah pengetahuan dan keterampilan Kader yang selama ini merasa tidak mengetahui tentang jenis-jenis penyakit mata, termasuk buta katarak. Koordinator Kader berhasil menghimpun 21 orang peserta pelatihan dari 11 Posyandu.

Kegiatan sosialisasi kepada Kepala Desa Cilayung beserta jajarannya ditujukan untuk mem-peroleh dukungan pada saat pelatihan maupun pasca-pelatihan, yakni memberikan dukungan kepada Kader dalam melaksanakan tugasnya.

Rencananya Tim PKM akan melakukan sosialisasi kepada Pengurus PKK Desa, namun demikian kami tidak sempat bertemu karena kesibukan pekerjaan mereka tetapi diantara kader peserta pelatihan ada juga yang merangkap jabatan sebagai anggota pengurus PKK Desa, sehingga mereka dianggap sebagai perwakilan dari PKK Desa.

\section{Persiapan Pelatihan}

Kegiatan ini mencakup penentuan jadwal pelaksanaan dan mempersiapkan berbagai kebutuhan sarana pelatihan. Jadwal pelatihan ditentukan bersamasama dengan Kader Kesehatan calon peserta pelatihan. Mereka memiliki kegiatan rutin bulanan di setiap Posyandu secara bergiliran mulai minggu kedua kecuali hari sabtu dan minggu, sehingga kegiatan pelatihan hanya bisa dilakukan di minggu pertama atau minggu terakhir.

Tim juga mempersiapkan berbagai kebutuhan bahan pelatihan cetakan, seperti alat peraga berupa poster yang berisi gambar ciri-ciri mata terindikasi katarak; alat bantu identifikasi katarak berupa E chart yang dapat ditempel di dinding dan E chart kecil berukuran 20 x 20 $\mathrm{cm}$ yang praktis untuk dibawa dan dapat masuk ke tas wanita; lampu senter kecil; dan beberapa jenis alat tulis. 


\section{Pelaksanaan Pelatihan}

Kegiatan pelatihan dilaksanakan dalam tiga kali pertemuan. Pertemuan pertama dan kedua dilakukan di kelas mencakup materi: a) latar belakang pelatihan; b) pengenalan katarak dan berbagai penyakit mata lainnya; c) pengenalan alat bantu dalam mengidentifikasi katarak dan pelatihan cara penggunaannya, dengan menggunakan metoda role playing diantara peserta pelatihan. Selain itu, semua peserta pelatihan diberi penugasan agar bekerjasama untuk menghadirkan satu atau dua orang warga diduga penderita katarak pada pertemuan kedua. Pertemuan kedua mencakup kegiatan: a) penguatan keterampilan dalam penggunaan alat bantu dan pengenalan ciri-ciri katarak dengan mengamati kasus warga diduga penderita katarak yang turut dihadirkan dalam kegiatan pelatihan ini; b) pencatatan data sesuai kebutuhan penyelenggara pelayanan operasi katarak; c) pengenalan masalah non-medis pada penanganan kasus warga terduga menderita katarak dan peran pendampingan yang dapat dilakukan Kader; d) pengenalan pelayanan tindakan operasi katarak dan lembaga penyelenggaranya. Selain itu, dilakukan pembentukan Kelompok Kader Katarak sekaligus pemilihan kepengurusan agar diantara mereka terjalin hubungan dan kerjasama untuk saling mendukung dan berbagi pengetahuan dan pengalaman, serta dapat memecahkan masalah secara besamasama. Setiap peserta pelatihan diberi penugasan untuk mengidentifikasi warga diduga menderita katarak di wilayah binaan mereka; dan sekaligus melakukan pencatatan.

Peserta antusias mengikuti kegiatan pelatihan. Semua peserta mencoba menggunakan alat bantu EChart besar dan E Chart kecil untuk memeriksa kemampuan penglihatan warga yang diperiksa (Gambar 1), dan jika dalam jarak dekat tidak mampu melihat, maka pemeriksaan dilanjutkan dengan menggunakan lampu senterkeciluntukmemastikan adanya ciri-ciri katarak dalam lensa mata warga yang diperiksa (Gambar 2). Dalam kegiatan pelatihan ini hadir satu orang warga yang mengalami gangguan penglihatan, dan setelah diperiksa ternyata menderita katarak. Untuk pelaksanaan tugas Kader selanjutnya, kepada setiap Posyandu diberikan E Chart besar dan untuk setiap Kader peserta pelatihan diberikan E Chart kecil dan lampu senter

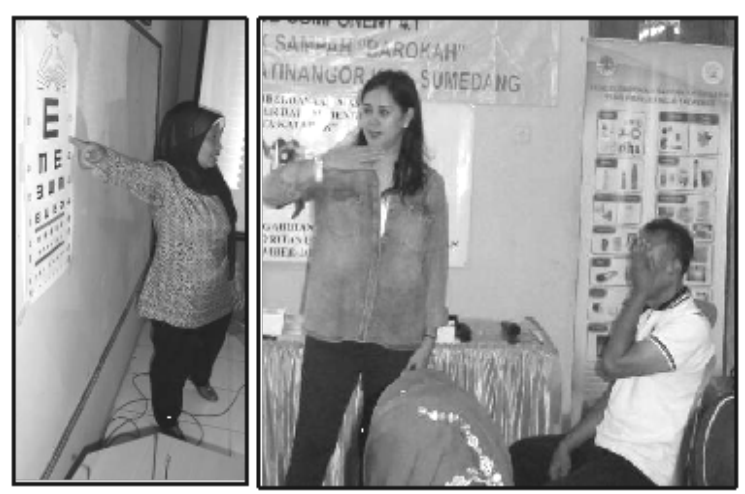

Gambar 1. Kader sedang mencoba memeriksa kondisi penglihatan warga dipandu oleh Pelatih

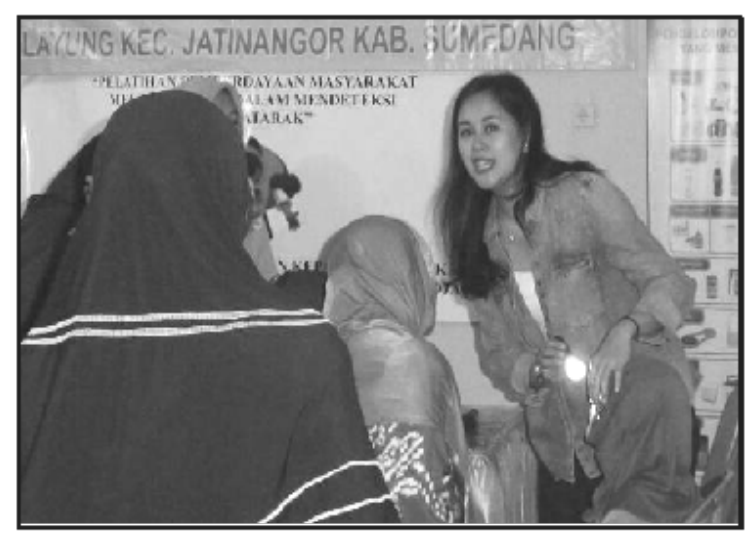

Gambar 2. Pelatih memperagakan cara mendeteksi katarak menggunakan lampu senter kecil

Pada pertemuan kedua, kembali dilakukan penguatan kemampuan dalam proses mengidentifikasi warga terduga penderita katarak melalui penyampaian materi tentang tahap kegiatan identifikasi warga terduga penderita katarak, mulai dari penelusuran warga yang mengalami gangguan mata yang mengarah ke kebutaan sampai dengan pencatatan data dan pelaporan; termasuk di dalamnya dengan siapa saja warga dapat bekerja sama. Dalam proses ini dijelaskan peran yang dapat dilakukan oleh Kader pada setiap tahapan kegiatan (Gambar 3).

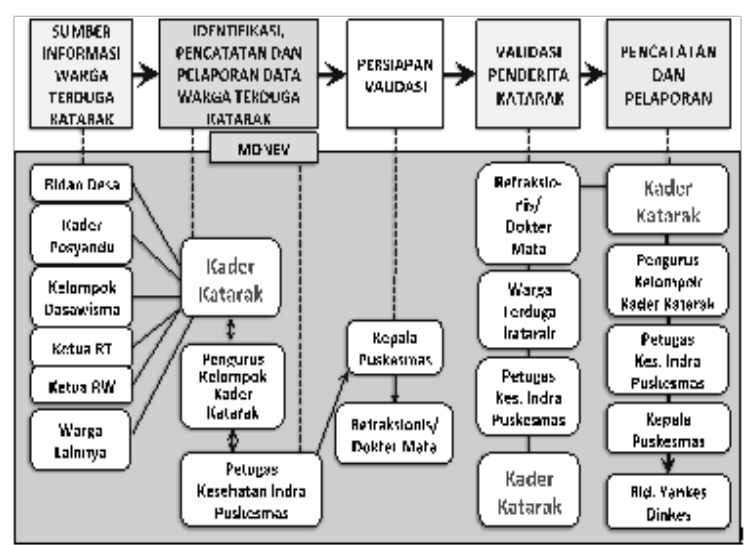

Gambar 3. Tugas Kader Katarak dalam Proses Identifikasi Warga Terduga Penderita Katarak

Sebagai bekal untuk melaksanakan tugas pendampingan, Kader peserta pelatihan mendapatkan penjelasan tentang persyaratan administratif yang harus dipenuhi oleh pasien yang akan menjalani tindakan operasi, yaitu: 1) Menyerahkan fotocopy Kartu Tanda Penduduk, fotocopy Kartu Keluarga, dan Surat Keterangan Tidak Mampu (SKTM) dari RT/RW; 2) Usia penderita lebih dari 14 tahun dan kooperatif; 3) Penderita tidak sedang mengalami penyakit kencing manis, tekanan darah tinggi, hepatitis, AIDS, infeksi pada mata dan myopia sangat tinggi. Bagi pasien yang telah menjalani tindakan operasi, Kader Kesehatan dapat ikut memastikan bahwa pasien: 1) menjalani pemeriksaan hari $\mathrm{H}+1$ dan hari $\mathrm{H}+7$ setelah tindakan operasi; 2) menjaga mata jangan terkena air dan digosok-gosok atau dikucek; 3) tidak mengangkat benda berat dan tidak sujud atau ruku pada saat sholat seperti dalam keadaan normal. 
Peserta pelatihan juga mendapat penjelasan tentang penyelenggara pelayanan tindakan operasi. Materi ini disampaikan oleh Penggiat Komunitas Masyarakat Peduli Jabar yang setiap bulan ikut mengelola klinik yang menyelenggarakan kegiatan bakti sosial pelayanan tindakan operasi katarak, terutama bagi kelompok masyarakat yang tidak mampu. Materi pelatihan ini sangat diperlukan oleh Kader peserta pelatihan yang akan berperan sebagai Kader Katarak. Biasanya Kader menemukan warga yang menderita katarak tetapi tidak tahu bagaimana membantu mangatasinya.

Di akhir pertemuan kedua setiap Kader ditugasi untuk menelusuri warga yang mengalami gangguan penglihatan dengan ciri-ciri yang mengindikasikan mengalami gangguan akibat katarak; mendeteksinya, sekaligus mencatat dan membuat laporan.

Dalam kegiatan pelatihan ini selalu hadir Kepala Urusan Kesejahteraan Rakyat Desa Cilayung yang diantaranya mengurusi bidang kesehatan. Beliau merupakan wakil dari pihak Desa Cilayung yang siap untuk memberi dukungan kepada para Kader dalam melaksanakan tugasnya, terutama dalam mensosialisasikan keberadaan Kader Katarak di wilayah Desa Cilayung kepada para Kepala Dusun dan Ketua RW yang berada di lingkungannya, dan mengajak mereka untuk memberikan dukungan. Warga penderita katarak yang tidak mampu yang memerlukan tindakan operasi memerlukan bantuan Ketua RW dan Ketua RT dalam penerbitan surat keterangan tidak mampu (SKTM), yang merupakan salah satu persyaratan administratif tindakan operasi "gratis".

Petugas Program Kesehatan Indra Puskesmas DTP Jatinangor, sebenarnya diundang dalam kegiatan pelatihan ini tetapi berhalangan hadir. Kami Tim Pelaksana PKM menganggap kehadiran Petugas Program Kesehatan Indra dalam kegiatan pelatihan ini penting karena terkait dengan tugas dan fungsinya. Namun demikian, kami Tim Pelaksana menyampaikan hasil kegiatan ini berikut daftar Kader yang telah mengikuti pelatihan, agar selanjutnya mereka dibina dan dapat menjadi mitra kerjasama bagi Puskesmas dalam penanganan buta katarak. Selain itu, Puskesmas diharapkan dapat memberikan fasilitasi jika mereka mengalami kesulitan atau kendala dalam melaksanakan tugasnya.

Pertemuan ketiga merupakan kegiatan monitoring dan evaluasi untuk memastikan bahwa Kader Katarak terus berupaya mempraktikkan keterampilannya dalam mengidentifikasi warga terduga penderita katarak. Tim Pelaksana PKM terus melakukan kontak dengan Kader Katarak, baik dengan ketua kelompok maupun anggotanya untuk memastikan apakah kegiatan penelusuran kasus warga terduga katarak terus dilakukan. Selain warga yang sudah teridentifikasi sebagai penderita katarak, yang pada saat pelatihan dihadirkan dan diperiksa secara bersamasama oleh peserta pelatihan dan divalidasi oleh pelatih; Kader di RW 03 menemukan 2 kasus warga terduga menderita katarak. Keduanya masih perlu divalidasi apakah mereka benar-benar menderita katarak yang dapat ditangani dengan tindakan operasi.

Hasil identifikasi dan pencatatan warga terduga menderita katarak merupakan data mikro yang dapat digunakan oleh Kader Kesehatan maupun Petugas Program Kesehatan Indra Puskesmas Jatinangor untuk ditindaklanjuti; agar penderita katarak, terutama dari kelompok masyarakat miskin, dapat mengakses pelayanan tindakan operasi.

Pasca pelatihan Kader Katarak tampaknya masih bersemangat untuk dapat menemukan kasus warga terduga penderita katarak, namun demikian kegiatan mereka relatif banyak. Kader biasanya ikut serta dalam rapat koordinasi di Desa, melaksanakan kegiatan rutin di Posyandu, membantu warga yang melahirkan di Polindes, dan beberapa kegiatan lainnya yang tidak bersifat rutin. Untuk melakukan kegiatan identifikasi katarak sebenarnya Kader tidak harus menyediakan waktu khusus tetapi dapat dilakukan sambil melakukan kegiatan lainnya. Peran mereka sebagai Kader Katarak memang baru mereka sandang, sehingga mereka masih memerlukan cukup waktu untuk mensosialisasikan peran baru tersebut kepada warga.

Di dalam setiap komunitas terdapat kapasitas berupa sence of community, commitment, the ability to solve problems, dan access to resources dalam tingkatan yang berbeda. Keempat karakteristik kapasitas ini berada pada tingkatan individu, organisasi, dan jaringan sosial. Kapasitas komunitas tersebut dapat diungkit melalui upaya pengembangan kapasitas untuk digunakan dalam pemecahan masalah bersama (Chaskin, 2001). Kegiatan pengabdian kepada masyarakat ini dapat meningkatkan kapasitas individu kader kesehatan. Mereka sedikitnya memiliki pengetahuan dan keterampilan dalam mengidentifikasi warga terduga penderita katarak dengan menggunakan alat-alat bantu sederhana; dan dalam melakukan pencatatan dan pelaporan. Mereka juga terhimpun dalam suatu kelompok sebagai wadah untuk berbagi pengalaman diantara mereka; belajar berjejaring dan berkolaborasi dengan berbagai komponen komunitas terkait dalam mendeteksi warga terduga penderita katarak.

Kegiatan pengembangan kapasitas individu ini seyogyanya ditindaklanjuti dengan kegiatan pengembangan kapasitas jaringan sosial melalui upaya pengorganisasian komunitas, agar semua komponen komunitas terkait yang diharapkan berperan dalam mendukung kader katarak dapat berperan dengan baik. Pathare mengatakan bahwa tujuan pengorganisasian komunitas adalah meningkatkan kapasitas komunitas agar komunitas tersebut lebih terorganisasi untuk menangani kebutuhan atau masalahnya sendiri (Pathare, http://www.ignou.ac.in/upload/bswe-03-block1-unit-1small-size.pdf). Keterhubungan (linkage) individu dan institusi sosial yang bekerjasama dalam sebuah jaringan sosial merupakan kapital sosial yang dapat digunakan untuk memecahkan masalah bersama (Uphoff, 2000; 
Warner, 2001). Oleh karena itu, kegiatan ini akan menjadi agenda kegiatan PKM berikutnya. Aparat desa yang turut mengikuti kegiatan pelatihan ini dan Petugas Pelaksana Program Kesehatan Indra di Puskesmas Jatinangor dapat menjadi mitra dalam kegiatan tersebut.

Keberadaan Kader Katarak di Desa Cilayung merupakan aset bagi Puskesmas DTP Jatinangor. pengetahuan dan keterampilan mereka dalam mengidentifikasi warga terduga menderita katarak dapat menjadi bekal untuk menjangkau warga yang selama ini belum terperhatikan dan terdeteksi sebagai warga terduga penderita katarak. Hasil penjangkauan Kader Katarak dapat memungkinkan mereka untuk mendapatkan pelayanan tindakan operasi.

Petugas Program Kesehatan Indra di Puskesmas Jatinangor seyogyanya mulai memfokuskan perhatian pada penanganan katarak; karena relatif banyak fasilitas yang dapat dimanfaatkan; sementara dampaknya relatif besar karena dapat mendukung atau mengembalikan produktivitas penderita katarak dalam menjalankan kehidupannya sehari-hari.

\section{SIMPULAN}

Keberadaan Kader Katarak sudah terbukti dapat memegang peranan penting dalam penemuan kasus warga terduga menderita katarak di wilayah yang sulit dijangkau. Walaupun Desa Cilayung Kecamatan Jatinangor relatif dekat dengan fasilitas kesehatan mata, namun penemuan kasus warga terduga menderita katarak masih diperlukan. Petugas Program Kesehatan Indra di Puskesmas akan sangat terbantu jika di wilayah binaannya terdapat Kader Katarak. Namun demikian, diperlukan upaya kreatif dari Petugas Program Kesehatan Indra di Puskesmas untuk melakukan pendekatan kepada Kader dan menjalin kerjasama dengan berbagai pemangku kepentingan terkait; baik dengan komponen komunitas di tingkat desa; perguruan tinggi dalam upaya peningkatan kapasitas kader katarak; maupun dengan penyelenggara pelayanan tindakan operasi katarak.

\section{UCAPAN TERIMA KASIH}

Kamimenghaturkan terima kasih kepada Direktorat Jenderal Pendidikan Tinggi sebagai penyelenggara Program PPM Prioritas; kepada Pimpinan dan Staf LPPM Universitas Padjadjaran sebagai pendukung utama dalam setiap tahapan kegiatan Program PPM Prioritas; kepada Kepala Puskesmas DTP Jatinangor, Petugas Program Kesehatan Indra, Kepala Desa Cilayung dan jajarannya, dan para Kader Kesehatan peserta pelatihan atas kesempatan dan dukungan yang telah diberikan, sehingga kegiatan PKM ini dapat terlaksana sesuai dengan yang diharapkan.

\section{DAFTAR PUSTAKA}

Asbell PA, Dualan I, Mindel J, Brocks D, Ahmad M, Epstein S. (2005) Age-Related Cataract. Lancet. Feb 12-18 2005;365(9459):599-609.

Chaskin, R.J., Brown, P., Venlzatesh, S., Vidal, A. (2001). Building Community Capacity. New York: Aldine de Gruyer.

Kamil, Mustofa. Model-Model Pelatihan. https:// www.academia.edu/6077358/MODELMODEL_PELATIHAN_Oleh_Mustofa_ Kamil?auto=download

Kementerian Kesehatan RI. (2014). Situasi Gangguan Penglihatan dan Kebutaan. Jakarta: Pusat Data dan Informasi Kementerian Kesehatan RI.

Pathare, Suresh. Community Organisation: Concepts and Principles. http://www.ignou.ac.in/upload/ bswe-03-block1-unit-1-small-size.pdf.

Rodiah, S. Lusiana, E. dan Agustine M. (2016). Pemberdayaan Kader PKK dalam Usaha Penyebarluasan Informasi Kesehatan Jatinangor. Dharmakarya Vol. 5, No. 1, Mei 2016: 5-8

Rukmana, G.I.T, Yanti M. dan Sri S. (2016) Penambahan Jumlah Kader Kesehatan dan Peningkatan Pengetahuan Mengenai Kanker Payudara Serta Pelatihan Pemeriksaan Payudara Sendiri (Sadari) di Desa Cinyasag dan Desa Girilaya Kecamatan Panawangan Ciamis. Dharmakarya Vol. 5, No. 1, Mei 2016: 44 - 46

Sulastri, S., Rusmana, A., Khadijah, U.L.S. (2015). Model Pencegahan dan Penanganan Katarak Berbasis Komunitas untuk Menurunkan Prevalensi Katarak di Wilayah Jawa Barat Selatan. Laporan Penelitian, Bandung: LPPM Universitas Padjadjaran.

Uphoff, Norman. (2000). Understanding Social Capital: Learning from the Analysis and Experience of Participation. Dalam Dasgupta, P. dan Serageldin, I. (Editor). Social Capital: A Multifaceted Perspective, hlm. 215-249. Washington D.C.: The World Bank.

Warner, M. (2001). Building Sosial Capital: The Role of Local Government. The Journal of SocioEconomics 30:187-192. E. 